... Aydemir, Alsan, Can, Altuntas, Sivrikaya: Accelerated Weathering and Decay Resistance...

\title{
Accelerated Weathering and Decay Resistance of Heat-Treated Wood Reinforced Polypropylene Composites
}

\section{Ubrzano izlaganje polipropilenskih kompozita ojačanih pregrijanim drvom vremenskim utjecajima i otpornost na propadanje}

\author{
Original scientific paper • Izvorni znanstveni rad \\ Received-prispjelo: 27. 11. 2018. \\ Accepted-prihvaćeno: 4. 7. 2019. \\ UDK: $630 * 814.111 ; 630 * 863$ \\ https://doi.org/10.5552/drvind.2019.1851
}

\begin{abstract}
The aim of this study was to determine the accelerated weathering and decay resistance of the heattreated wood reinforced polypropylene composites (HT-WPC). Polypropylene (PP) was used as a matrix and the heat-treated wood treated at $180^{\circ} \mathrm{C}$ and $220^{\circ} \mathrm{C}$ as reinforcement filler. The effect of three filler type, such as 40 , 60 and 100 mesh, on the outdoor performance of composites was also investigated. The composites were prepared with twin screw extruder, and the test samples were obtained with compression molding. Lightness index $\left(L^{*}\right)$, color changes $\left(\Delta E^{*}\right)$ and physical changes on the surface of the composites after the accelerated weathering, and decay resistance of the composites were investigated. According to the results, the effects of heat-treated wood on color changes were found to be more than its filler size, and while the filler loadings were increased from $5 \%$ to $20 \%$, it was determined to increase the color changes of the composites. In scanning electron microscopy (SEM) images, crack formation and deterioration on the surface of the composites were determined. In FTIR spectra, no difference was determined between the composites, and all peaks were similar to each one. The addition of heattreated wood improved the antifungal efficiency of the composite, and the mass losses decreased with the increasing of heat treatment temperature. As a result, adding heat-treated wood to PP was found to improve the outdoor performance of the HT-WPCs.
\end{abstract}

Keywords: wood polymer composites, heat-treated wood, polypropylene (PP), outdoor performance, thermoplastics

SAŽETAK • Cilj ovog rada bio je utvrditi otpornost na propadanje polipropilenskih kompozita ojačanih pregrijanim drvom (HT-WPC) pri ubrzanom izlaganju vremenskim utjecajima. Polipropilen (PP) upotrijebljen je kao matrica, a drvo pregrijano na 180 i $220{ }^{\circ} \mathrm{C}$ kao armaturno punilo. Ispitivan je i učinak triju vrsta punila (mreža 40, 60 i 100) na svojstva kompozita u eksterijeru. Kompoziti su pripremljeni dvostrukim vijčanim ekstruderom,

\footnotetext{
Authors are researchers at Bartin University, Faculty of Forestry, Department of Forest Industrial Engineering, Bartin, Turkey. ${ }^{2}$ Author is researcher at Kahramanmaras Sutcu Imam University, Faculty of Forestry, Department of Forest Industrial Engineering, Kahramanmaras, Turkey.

${ }^{1}$ Autori su istraživači Sveučilišta Bartin, Šumarski fakultet, Zavod za inženjerstvo u šumarstvu, Bartin, Turska. ${ }^{2}$ Autor je istraživač Sveučilišta Kahramanmaras Sutcu Imam, Šumarski fakultet, Zavod za inženjerstvo u šumarstvu, Kahramanmaras, Turska.
} 
a ispitni su uzorci dobiveni kompresijskim lijevanjem. Ispitivana je svjetlina $\left(L^{*}\right)$, promjena boje $\left(\Delta E^{*}\right)$ i fizičke promjene na površini kompozita nakon ubrzanog izlaganja vremenskim utjecajima, kao i otpornost na propadanje kompozita. Prema dobivenim rezultatima, utvrđeno je da su učinci pregrijavanja drva na promjenu boje veći od učinka veličine punila. Nadalje, zamijećeno je povećanje promjene boje kompozita s povećanjem udjela punila od 5 na $20 \%$. Na snimkama dobivenim elektronskim mikroskopom (SEM) uočeno je stvaranje pukotina i propadanje površine kompozita. Međutim, na FTIR spektru nije ustanovljena razlika između kompozita i svi su vrhovi bili slični. Dodavanjem pregrijanog drva poboljšala se otpornost kompozita na gljive te se smanjio gubitak mase $s$ povećanjem temperature pregrijavanja. Utvrđeno je da se dodavanjem pregrijanog drva u polipropilen (PP) poboljšavaju svojstva kompozita HT-WPC-a u eksterijeru.

Ključne riječi: drvno-plastični kompoziti, pregrijano drvo, polipropilen (PP), svojstva u eksterijeru, termoplasti

\section{INTRODUCTION}

\section{UVOD}

Wood polymer composites (WPCs) have been of interest due to major advantages such as cost, durability, high mechanical properties, etc. WPC has two main constituents: wood and polyolefins. The addition of wood can provide an increase in the mechanical properties of the WPC as compared with neat polymer (Kallakas et al., 2015). However, wood is a biological material, which is degraded by biological degradation factors such as fungi, insect, bacteria, etc. It also has a hygroscopic structure, and it can absorb a lot of water in a wet medium or desorb by evaporating the water outside the cell in a dry medium. The behavior turns the wood into, dimensionally, an unstable structure. Therefore, in many outdoor applications, the durability and dimensional stability of wood is an important issue for the WPC performance. Biological durability of wood is known as a significant drawback of polymer composites reinforced with wood in outdoor conditions (Luo et al., 2012). Pilarski and Matuana (2005) observed that the composites absorbed more moisture in outdoor uses, and some deterioration of the interfacial adhesion between the wood flour and the polymer matrix was seen. Naumann et al. (2012) reported the formation of micro- and macrocracks in the surface of the wood polymer composite due to outdoor use. The results showed that the cracks cause the enhancement of moisture sorption and microbial attacks due to the weathering under UV radiation, water spray. Many studies in the literature have reported that the deteriorations occurred on the surface of the composites due to higher moisture content after the natural and artificial weathering (Kallakas et al., 2015; Stark and Gardner, 2008; Butylina and Karki, 2014; Yilgor et al., 2014; Lopez-Naranjo et al., 2016). To eliminate these drawbacks, many studies related to the heat treatment in terms of different properties, such as the physical and mechanical properties of wood materials, were conducted (Aytekin et al.; 2009, Gunduz et al., 2009; Kaygin et al., 2009; Kaygin et al., 2014). The heat treatment also improves the water sorption and fungal resistance of wood (Gunduz et al., 2009; Gunduz et al., 2010; Žlahtič-Zupanc et al., 2018). When wood is thermally modified at a temperature of $180^{\circ} \mathrm{C}$ and above, its thermal properties can also be improved because some components of wood are decomposed or at least have gone through various changes in its structure after the heat-treatment (Segerholm et al., 2012; Kaboorani,
2009; Pelaez-Samaniego et al., 2013; Karakus et al., 2017).

The objective of this paper was to investigate the accelerated weathering performance and decay resistance of the heat-treated wood reinforced polypropylene composites in various filler sizes and loadings and to determine the feasibility of heat-treated wood in polymer composites for outdoor applications as an alternative to untreated wood.

\section{MATERIALS AND METHODS \\ 2. MATERIJALI I METODE}

\subsection{Materials}

2.1. Materijali

Polypropylene matrix used in the study was obtained by Petkim Inc. (Turkey, Izmir). It has a density of $0.90 \mathrm{~g} / \mathrm{cm}^{3}$, melt flow index of $24 \mathrm{~g} / \mathrm{min}$ and melting temperature $\left(T_{m}\right)$ of $180{ }^{\circ} \mathrm{C}$. Beech (Fagus orientalis L.) wood used as filler was kindly supplied by the local timber mill. (Bartin, Turkey). The heat-treated wood was prepared at $180^{\circ} \mathrm{C}(\mathrm{HT} 1)$ and $220^{\circ} \mathrm{C}(\mathrm{HT} 2)$ for 4 hours in a heating cabin with $\pm 1{ }^{\circ} \mathrm{C}$ sensitivity. Both the heat-treated and untreated wood were ground to small diameters of 40, 60 and 100 mesh to determine the effects of filler size and amount on the outdoor performance of the composites.

\subsection{Preparation of composites \\ 2.2. Priprema kompozita}

Polypropylene was separately mixed with both the untreated (UT) and heat-treated wood (HT). The compounding was provided with a twin-screw extruder (Gulnar Extruder, Turkey) at a temperature of $180^{\circ} \mathrm{C}$ and rotor speed of $65 \mathrm{~min}^{-1}$. The polymer-wood blends were granulated after water bath, they were dried at $(105 \pm 2){ }^{\circ} \mathrm{C}$ for $24 \mathrm{~h}$, and all blends were compression molded at the processing temperature of $180{ }^{\circ} \mathrm{C}$ and the injection pressure of $25 \mathrm{~kg} / \mathrm{cm}^{2}$. The formulations of the composites are shown in Table 1.

\subsection{Characterization of composites}

2.3. Karakterizacija kompozita

2.3.1 Accelerated weathering performance (QUV)

2.3.1. Ubrzano izlaganje vremenskim utjecajima (QUV)

The accelerated weathering tests were performed by cycles of UV-light irradiation during 500 hours in a QUV test cycle chamber according to ASTM G154. 
... Aydemir, Alsan, Can, Altuntas, Sivrikaya: Accelerated Weathering and Decay Resistance...

Table 1 Formulations of composites

Tablica 1. Formulacije kompozita

\begin{tabular}{|c|c|c|c|c|}
\hline $\begin{array}{c}\text { Samples } \\
\text { Uzorci }\end{array}$ & $\begin{array}{l}\text { Filler type } \\
\text { Vrsta punila }\end{array}$ & $\begin{array}{l}\text { Filler size, mesh } \\
\text { Veličina punila, mesh }\end{array}$ & $\begin{array}{l}\text { Filler loadings, \% } \\
\text { Udio punila, \% }\end{array}$ & $\begin{array}{r}\text { Polymer, \% } \\
\text { Polimer, \% }\end{array}$ \\
\hline PP & & & & 100 \\
\hline UT40 5 & Untreated (UT) & \multirow{3}{*}{40} & \multirow{3}{*}{5} & \multirow{3}{*}{95} \\
\hline HT1-40_5 & Treated at $180^{\circ} \mathrm{C}(\mathrm{HT} 1)$ & & & \\
\hline HT2-40_5 & Treated at $220^{\circ} \mathrm{C}(\mathrm{HT} 2)$ & & & \\
\hline UT40_20 & Untreated (UT) & \multirow{3}{*}{40} & \multirow{3}{*}{20} & \multirow{3}{*}{80} \\
\hline HT1-40_20 & Treated at $180^{\circ} \mathrm{C}(\mathrm{HT} 1)$ & & & \\
\hline HT2-40_20 & Treated at $220^{\circ} \mathrm{C}(\mathrm{HT} 2)$ & & & \\
\hline UT60_5 & Untreated (UT) & \multirow{3}{*}{60} & \multirow{3}{*}{5} & \multirow{3}{*}{95} \\
\hline HT1-60_5 & Treated at $180^{\circ} \mathrm{C}(\mathrm{HT} 1)$ & & & \\
\hline HT2-60_ 5 & Treated at $220^{\circ} \mathrm{C}(\mathrm{HT} 2)$ & & & \\
\hline UT60_20 & Untreated (UT) & \multirow{3}{*}{60} & \multirow{3}{*}{20} & \multirow{3}{*}{80} \\
\hline HT1-60_20 & Treated at $180^{\circ} \mathrm{C}(\mathrm{HT} 1)$ & & & \\
\hline HT2-60_20 & Treated at $220^{\circ} \mathrm{C}(\mathrm{HT} 2)$ & & & \\
\hline UT100_5 & Untreated (UT) & \multirow{3}{*}{100} & \multirow{3}{*}{5} & \multirow{3}{*}{95} \\
\hline HT1-100_5 & Treated at $180^{\circ} \mathrm{C}(\mathrm{HT} 1)$ & & & \\
\hline HT2-100_5 & Treated at $220^{\circ} \mathrm{C}(\mathrm{HT} 2)$ & & & \\
\hline UT100_20 & Untreated (UT) & \multirow{3}{*}{100} & \multirow{3}{*}{20} & \multirow{3}{*}{80} \\
\hline HT1-100_20 & Treated at $180^{\circ} \mathrm{C}(\mathrm{HT} 1)$ & & & \\
\hline HT2-100_20 & Treated at $220^{\circ} \mathrm{C}(\mathrm{HT} 2)$ & & & \\
\hline
\end{tabular}

The average irradiance level was $0.85 \mathrm{~W} / \mathrm{m}^{2}$ at $340 \mathrm{~nm}$ and the temperature in the chamber was approximately $50{ }^{\circ} \mathrm{C}$. Three replicates of each composite were used. After the QUV test, color changes were determined and surface characterization with SEM of all the composites was conducted.

\subsubsection{Color measurement \\ 2.3.2. Mjerenje boje}

Color changes were determined with a Konica Minolta spectrophotometer (Osaka, Japan) by measuring the $L$, a and $\mathrm{b}$ values on the specimens. For each specimen, four-color measurement was made and the color analysis was carried out according to ISO 7724-2 standard. The changes in color coordinates $\left(\Delta L^{*}, \Delta a^{*}\right.$ and $\left.\Delta b^{*}\right)$ were determined with the difference between the initial and final values. The total color changes $\left(\Delta E^{*}\right)$ were calculated according to the following equations:

$$
\left(\Delta E^{*}\right)=\left[\left(\Delta a^{*}\right)^{2}+\left(\Delta b^{*}\right)^{2}+\left(\Delta L^{*}\right) 2\right] 1 / 2
$$

\subsubsection{Determination of antifungal efficiency}

\subsubsection{Određivanje otpornosti na gljive}

Decay test was carried out on the composites during 12 weeks in a climate chamber with a temperature of $23{ }^{\circ} \mathrm{C}$ and relative humidity of $70 \%$ according to the principles of EN 113. Test specimens were prepared in dimensions of $30 \mathrm{~mm} \times 12 \mathrm{~mm} \times 2 \mathrm{~mm}$. White rot fungi were used in the test because hardwood was used for the production of WPCs. The decay test for white rot, T. versicolor (L.: Fr.) Pilat was based on the specimens on $48 \%$ malt extract agar in Petri dishes. At the end of the exposure time, the mycelia layers on the surfaces of the composites were removed and weighed. The mass loss was determined based on the dry mass before and after the decay test. Six replicates were used for each composite in the decay test.

\subsubsection{Scanning Electron Microscopy (SEM)}

2.3.4. Skenirajuća elektronska mikroskopija (SEM)

The morphological analysis of the composites was conducted with environmental scanning electron microscopy (ESEM) (Tescan MAIA3 XMU-SEM), with an accelerating voltage of $5 \mathrm{kV}$. For enhanced conductivity, the surface of all samples was sputtercoated with a blend of gold-palladium using a Denton sputter coater.

\subsubsection{Fourier Transfer Infrared Spectroscopy (FTIR) \\ 2.3.5. Fourierova transformacijska infracrvena spektroskopija (FTIR)}

The FTIR-ATR analysis was carried out with a Shimadzu IRAAffinity-1 spectrometer equipped with a single reflection ATR pike MIRacle sampling accessory. Four accumulated spectra with a resolution of 4 $\mathrm{cm}-1$ were obtained for wavenumbers from $800 \mathrm{~cm}^{-1}$ to $4000 \mathrm{~cm}^{-1}$ with 32 scans for each sample.

\section{RESULTS AND DISCUSSION 3. REZULTATI I RASPRAVA}

\subsection{Accelerated weathering performance}

3.1. Ubrzano izlaganje vremenskim utjecajima

The color and physical changes on the surface of the composites after the accelerated weathering were examined. Figure 1 and Figure 2 show the color changes $\left(\Delta E^{*}\right)$ as a percentage of all the composites.

As shown in Figure 1 and 2, it was determined that the filler size of wood had no important effect on the color changes after QUV exposure. The maximum color changes were found for the composites with wood treated at $220^{\circ} \mathrm{C}$ in all mesh sizes. It can be said that the status caused due to the heat-treated wood tends to grease rapidly in the weathering environment 


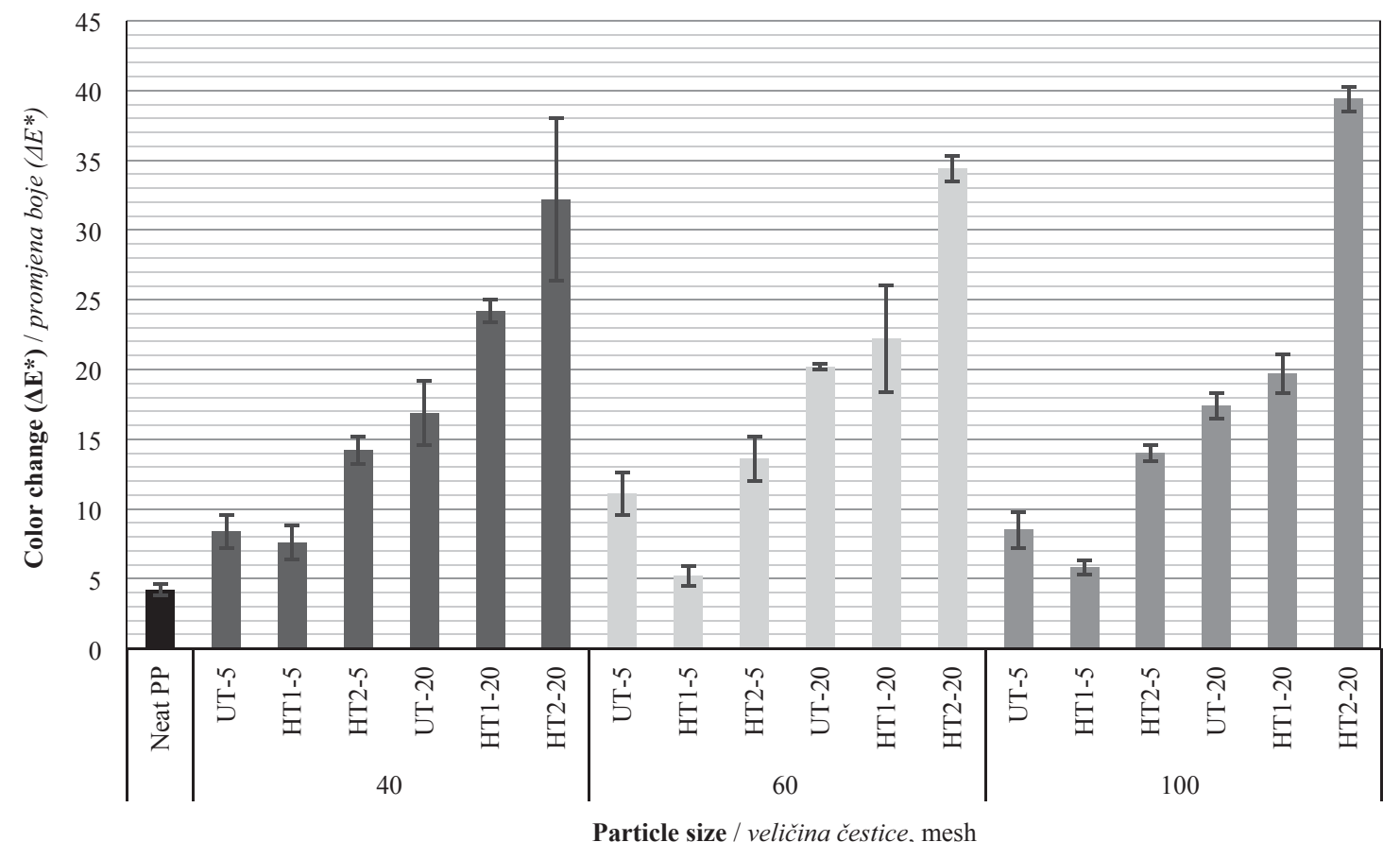

Figure 1 Color changes $\left(\Delta E^{*}\right)$ of all composites Slika 1. Promjena boje $\left(\Delta E^{*}\right)$ svih kompozita

(Baysal et al., 2014). The color changes in the composites with $20 \%$ wood filler were found to be higher than the composites with $5 \%$ wood filler. Hence, it can be said that the higher the addition of wood, the higher are the color changes. In a study, it was determined that the addition of the heat-treated wood to polymer composite had negative effects on the color change, and heattreatment was found to be ineffective in improving UV resistance of wood (Xing et al., 2015). After QUV test, whitening on the surface of the polypropylene composites with heat-treated wood was observed, and when heat-treatment temperature was raised from $180{ }^{\circ} \mathrm{C}$ to $220^{\circ} \mathrm{C}$, the whitening on the surface of polymer composites was found to increase. As shown by SEM im- ages in Figure 3, various small cracks and deep slits were also observed on the surfaces of the composites with both untreated and heat-treated wood as given in Figure $3 c$ and $d$, and the pieces of wood in the plastic matrix were observed to come to the surface of the composites (Figure $3 \mathrm{a}$ and $\mathrm{b}$ ). Similar results were obtained after the accelerated or natural weathering in other studies (Turku and Karki, 2016; Selden et al., 2004; Lee et al., 2012).

Table 2 shows the decay resistance of the composites with untreated and heat-treated wood. The weight losses of the composites with both heat-treated and untreated wood were determined to be higher than those of the neat polypropylene. The heat-treated wood

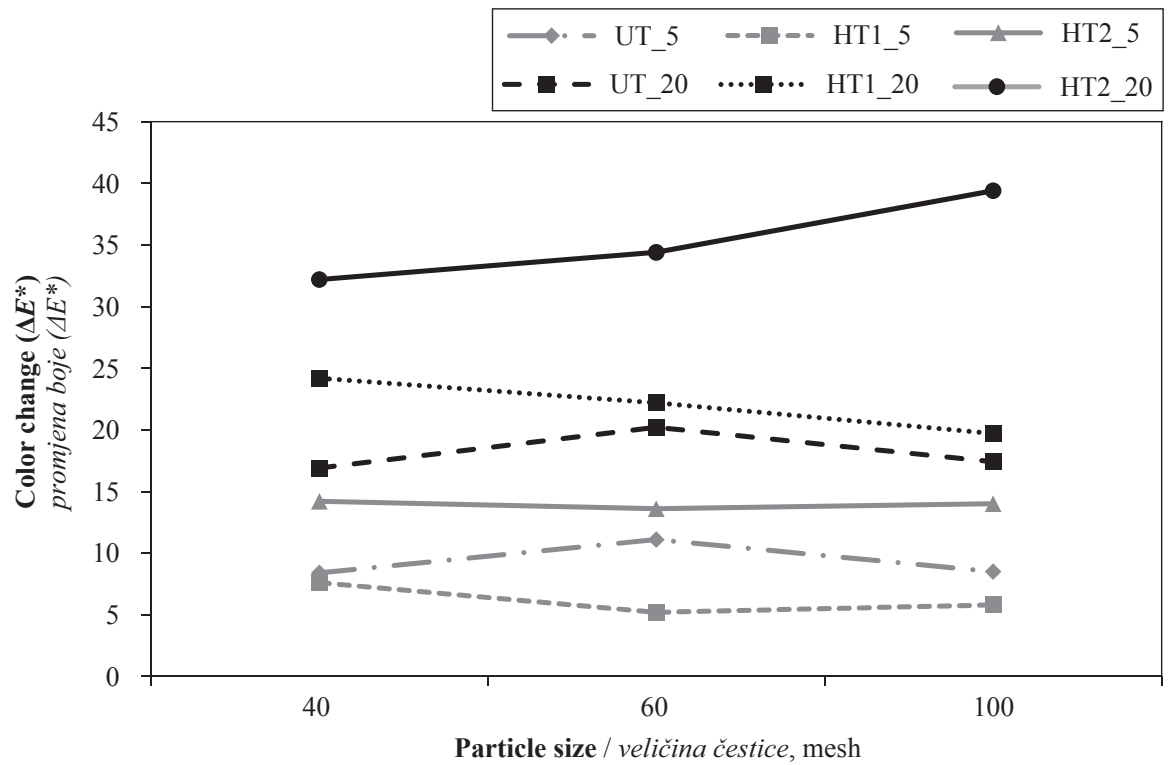

Figure 2 Color changes of composites according to filler size

Slika 2. Promjena boje kompozita s obzirom na veličinu punila 

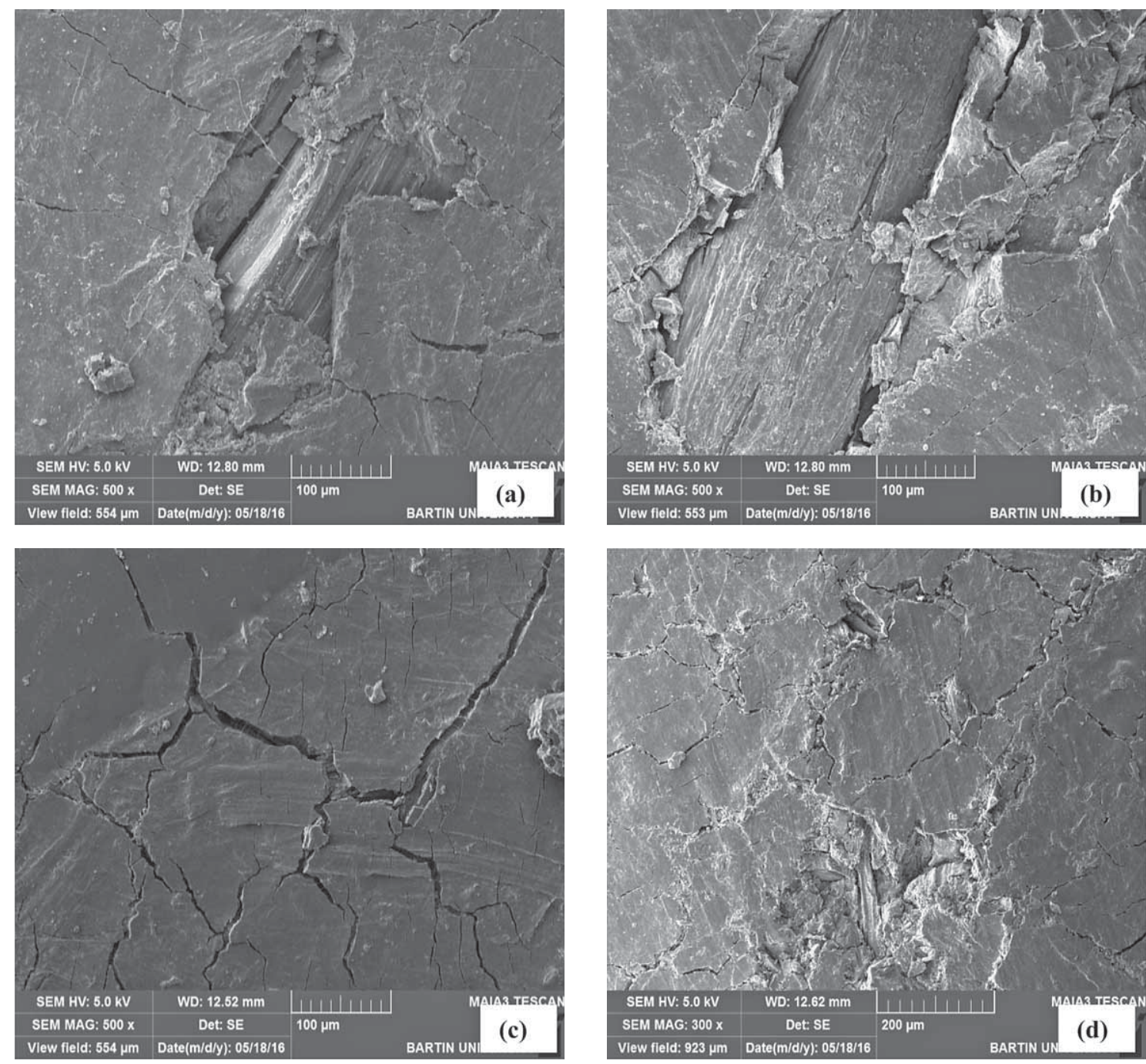

Figure 3 Physical changes on the surface of composites: (a, b) small pieces of wood, (c, d) surface deterioration and cracks Slika 3. Fizičke promjene na površini kompozita: (a, b) mali komadići drva, (c, d) propadanje površine i pukotine

Table 2 Mass loss of neat polypropylene and composites exposed to decay test

Tablica 2. Gubitak mase čistog polipropilena i kompozita izloženih testu propadanja

\begin{tabular}{|c|c|c|c|}
\hline $\begin{array}{c}\text { Samples } \\
\text { Uzorci }\end{array}$ & $\begin{array}{c}\text { Filler loading, \% } \\
\text { Udio punila, \% }\end{array}$ & $\begin{array}{c}\text { Mesh size } \\
\text { Veličina }\end{array}$ & $\begin{array}{c}\text { Mass loss, \% } \\
\text { Gubitak mase, \% }\end{array}$ \\
\hline Neat PP & & & $0.2( \pm 0.02)$ \\
\hline UT & \multirow{9}{*}{5} & \multirow{3}{*}{40} & $0.9( \pm 0.10)$ \\
\hline HT1 & & & $0.9( \pm 0.14)$ \\
\hline HT2 & & & $0.8( \pm 0.12)$ \\
\hline UT & & \multirow{3}{*}{60} & $1.4( \pm 0.14)$ \\
\hline HT1 & & & $1.0( \pm 0.12)$ \\
\hline HT2 & & & $0.9( \pm 0.13)$ \\
\hline UT & & \multirow{3}{*}{100} & $1.0( \pm 0.14)$ \\
\hline HT1 & & & $0.9( \pm 0.15)$ \\
\hline HT2 & & & $0.9( \pm 0.14)$ \\
\hline UT & \multirow{9}{*}{20} & \multirow{3}{*}{40} & $1.2( \pm 0.15)$ \\
\hline HT1 & & & $1.1( \pm 0.12)$ \\
\hline HT2 & & & $0.8( \pm 0.11)$ \\
\hline UT & & \multirow{3}{*}{60} & $1.6( \pm 0.16)$ \\
\hline HT1 & & & $1.5( \pm 0.15)$ \\
\hline HT2 & & & $1.1( \pm 0.12)$ \\
\hline UT & & \multirow{3}{*}{100} & $1.2( \pm 0.14)$ \\
\hline HT1 & & & $1.2( \pm 0.14)$ \\
\hline HT2 & & & $1.1( \pm 0.16)$ \\
\hline
\end{tabular}

was found to improve the decay resistance of the composites. However, decay resistance of all the composite was determined to be lower than that of the neat polypropylene. According to Table 2, the decay resistance of the composites with heat-treated wood was higher as compared with the composites with untreated wood. The results showed that the decay resistance of the composites decreased when the filler size decreased from 40 to 60 , while the decay resistance of the composites generally increased with 100 mesh wood filler. As a result, it can be said that both heat treatment of wood and filler loading and size have an effect on the decay resistance of the composites.

The weight loss was determined to range from $0.9 \%$ to $1.6 \%$, and the maximum and minimum mass losses were found for the composites with 60 mesh untreated wood for $20 \%$ loadings, and with 40 mesh heat-treated wood for $20 \%$ loadings.

\subsection{FTIR Analysis \\ 3.2. FTIR analiza}

The FTIR analysis was conducted to determine the chemical structure of neat PP, composites with untreated wood, wood heat-treated at $180{ }^{\circ} \mathrm{C}$ and $220^{\circ} \mathrm{C}$. The FTIR-ATR main peaks of neat PP, PP composites 


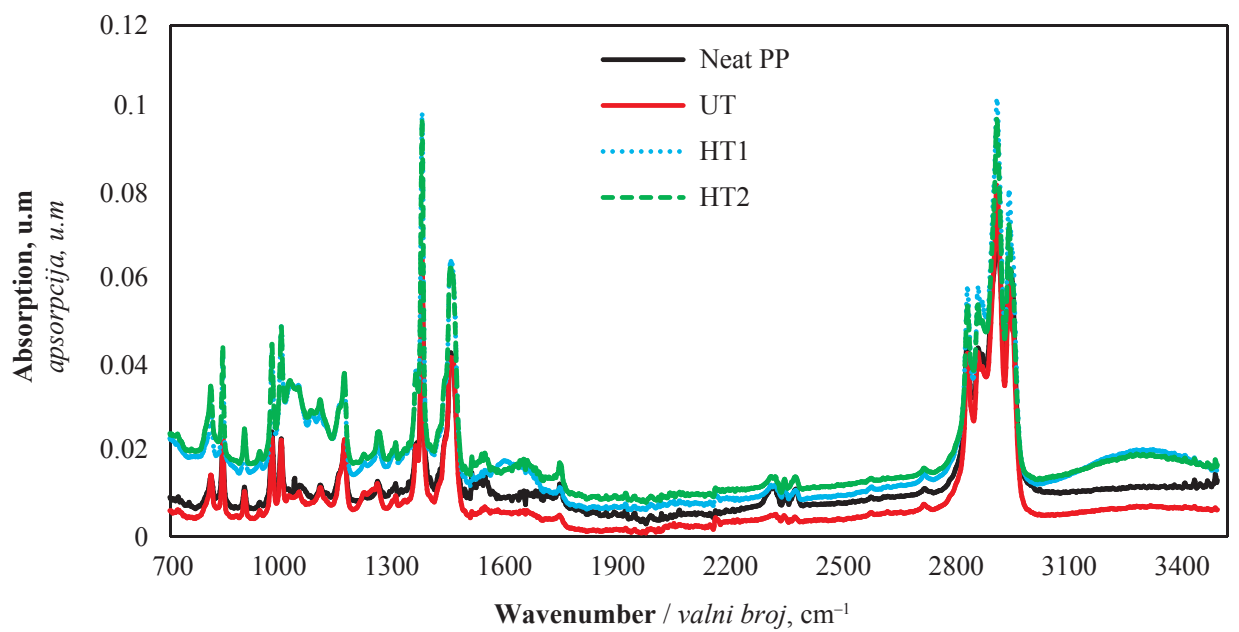

Figure 4 Spectra of neat polypropylene and composites with untreated and heat-treated wood Slika 4. Spektri čistog polipropilena i kompozita s nepregrijanim i pregrijanim drvom

Table 3 Spectra of neat polypropylene, and composites with untreated and heat-treated wood (Li et al., 2015; Ha et al., 2016)

Tablica 3. Spektri čistog polipropilena i kompozita s nepregrijanim i pregrijanim drvom (Li et al., 2015.; Ha et al., 2016.)

\begin{tabular}{|c|l|}
\hline $\begin{array}{c}\text { Wavenumber, } \mathbf{c m}^{-1} \\
\text { Valni broj, } \mathbf{c m}^{-1}\end{array}$ & \multicolumn{1}{|c|}{$\begin{array}{c}\text { Functional groups } \\
\text { Funkcionalne skupine }\end{array}$} \\
\hline 3300 & Hydroxyl groups of cellulose (-OH) \\
\hline 2950,2839 & $\mathrm{C}-\mathrm{H}$ stretch vibration of PP \\
\hline 1601 & $\begin{array}{l}\mathrm{C}=\mathrm{C} \text { stretch vibration of hemicellu- } \\
\text { lose }\end{array}$ \\
\hline 1457 & $-\mathrm{CH}_{2}$ bending vibration of PP \\
\hline 1376 & $-\mathrm{CH}_{3}$ bending vibration of PP \\
\hline 1167 & $\begin{array}{l}\text { Symmetric }-\mathrm{CH}_{3} \text { deformation } \\
\text { vibration }\end{array}$ \\
\hline 1043 & $\begin{array}{l}\mathrm{C}-\mathrm{O}-\mathrm{C} \text { and } \mathrm{C}-\mathrm{O} \text { groups of cellulose } \\
\text { and lignin }\end{array}$ \\
\hline 998,973 & $-\mathrm{CH}_{3}$ wagging vibration of PP \\
\hline
\end{tabular}

with untreated wood, wood heat-treated at $180^{\circ} \mathrm{C}$ and $220{ }^{\circ} \mathrm{C}$ are given in Figure 4.

According to Figure 4, the main spectra of neat polypropylene were ranged from $973 \mathrm{~cm}^{-1}$ to $2950 \mathrm{~cm}^{-}$ ${ }^{1} .1457 \mathrm{~cm}^{-1}$ and $1376 \mathrm{~cm}^{-1}$ peaks show $-\mathrm{CH}_{2}$ and $-\mathrm{CH}_{3}$ bending vibration of polypropylene (Sagativo et al., 2017). $1167 \mathrm{~cm}^{-1}, 998 \mathrm{~cm}^{-1}$, and $973 \mathrm{~cm}^{-1}$ peaks belong to $-\mathrm{CH}_{3}$ deformation vibration and $-\mathrm{CH}_{3}$ wagging vibration, respectively. $3300 \mathrm{~cm}^{-1}$ peak means $-\mathrm{OH}$ groups of cellulose and lignin in the composites with untreated wood (UT) and heat-treated wood (HT1 and HT2). $1601 \mathrm{~cm}^{-1}$ and $1043 \mathrm{~cm}^{-1}$ peaks show $\mathrm{C}=\mathrm{C}$ stretch of hemicellulose and $\mathrm{C}-\mathrm{O}-\mathrm{C}$ and $\mathrm{C}-\mathrm{O}$ stretch of carbohydrates in cellulose chains (Li et al., 2015; Ha et al., 2016) (Table 3). As a result, the structural properties of all the composites were observed to be similar.

\section{CONCLUSIONS}

\section{ZAKLJUČAK}

In the study, the accelerated weathering performance and decay resistance of the heat-treated wood reinforced polypropylene composites were investigated. SEM images of the specimens showed the deterioration and some cracks on the surface of the composites. According to the color change results, the effect of heat treatment on the color changes was higher than that of filler size, and while the filler loadings increased from $5 \%$ to $20 \%$, it was determined to increase the color changes of the composites. FTIR spectra showed that the composites had similar chemical structure. The decay test showed that the mass loss decreased with the increase of temperature in the heat-treatment of wood. The heat-treatment of wood showed to improve the antifungal efficiency of the composites. Finally, it can be said that heat-treated wood has more potential for related applications than the composite with untreated wood. However, the heat-treated wood tends to gray out rapidly in the weathering environment, which could be a drawback for common outdoor use.

\section{REFERENCES}

5. LITERATURA

1. Aytekin, A.; Gündüz, G.; Kaygin, B.; Korkut, S.; Onat, S. M., 2009. Drying schedules calculation of Camiyani Black Pine (Pinus nigra Arn. subsp. pallasiana var. pallasiana) by computer programming. African Journal of Biotechnology, 8 (8): 1703-1712.

2. Baysal, E.; Degirmentepe, S.; Simsek, H., 2014: Some surface properties of thermally modified scots pine after artificial weathering. Maderas. Ciencia y tecnología, 16 (3): $355-364$ https://doi.org/10.4067/S0718-221X2014005000028.

3. Butylina, S.; Kärki, T., 2014: Effect of Weathering on the Properties of Wood-polypropylene Composites Containing Minerals. Polymers \& Polymer Composites, 22 (9): 763. https://doi.org/10.1177/096739111402200902.

4. Gunduz, G.; Aydemir, D.; Karakas, G., 2009: The effects of thermal treatment on the mechanical properties of wild Pear (Pyrus elaeagnifolia Pall.) wood and changes in physical properties. Materials and Design, 30 (10): 43914395. https://doi.org/10.1016/j.matdes.2009.04.005.

5. Gunduz, G.; Aydemır, D.; Kaygın, B.; Aytekin, A., 2009: The effect of treatment time on dimensionally stability, moisture content and mechanical properties of heat treat- 
... Aydemir, Alsan, Can, Altuntas, Sivrikaya: Accelerated Weathering and Decay Resistance...

ed Anatolian chestnut (Castanea sativa Mill.) wood. Wood Research, 54 (2): 117-126.

6. Gunduz, G.; Aydemir, D.; Korkut, S., 2010: The effect of heat treatment on some mechanical properties and color changes of Uludag fir wood. Drying Technology, 28 (2): 249-255. https://doi.org/10.1080/07373930903530162.

7. Ha, H. A.-T.; Son, L.-T.; Viet, N. T.-B., 2016: Oil Sorbents Based on Methacrylic Acid - Grafted Polypropylene Fibers: Synthesis and Characterization. Journal of Chemical Engineering and Process Technology. 7 (2): 1-7. https://doi.org/10.4172/2157-7048.1000290.

8. Kaboorani, A., 2009: Thermal properties of composites made of heat-treated wood and polypropylene. Journal of Composite Materials, 43 (22): 2599-2607. https://doi.org/10.1177/0021998309345291.

9. Kallakas, H.; Poltimae, T.; Suld, T. M.; Kers, J.; Krumme, A., 2015: The influence of accelerated weathering on the mechanical and physical properties of wood-plastic composites. In: Proceedings of the Estonian Academy of Sciences, 64: 94-105. https://doi.org/10.3176/proc.2015.1S.05.

10. Karakus, K.; Aydemir, D.; Oztel, A.; Gunduz, G.; Mengeloglu, F., 2017: Nanoboron nitride filled heat-treated wood polymer nanocomposites: Comparison of three different multicriteria decision making models to predict optimum properties of the nanocomposites. Journal of Composite Materials, 51 (30): 4205-4218. https://doi.org/10.1177/0021998317699984.

11. Kaygin, B.; Gunduz, G.; Aydemir, D., 2009: The effect of mass loss on mechanic properties of heat-treated paulownia wood. Wood Research, 54 (2): 101-108.

12. Kaygin, B.; Koc, K. H.; Hiziroglu, S., 2014: Surface quality and hardness of eastern red cedar as function of steaming. Journal of Wood Science, 60 (4): 243-248. https://doi.org/10.1007/s10086-014-1399-x.

13. Lee, C. H.; Hung, K. C.; Chen, Y. L., 2012: Effects of polymeric matrix on accelerated UV weathering properties of wood-plastic composites. Holzforschung, 66: 981987. https://doi.org/10.1515/hf-2011-0198.

14. Li, G.; Lao, W.; Qin, T., 2015: Rapid determination of biomass and polypropylene in three types of wood plastic composites (WPCs) using FTIR spectroscopy and partial least squares regression (PLSR). Holzforschung, 69 (4): 399-404. https://doi.org/10.1515/hf-2014-0157.

15. Lopez-Naranjo, E. J.; Alzate-Gaviria, L. M.; HernándezZárate, G.; Reyes-Trujeque, J.; Cruz-Estrada, R. H., 2016: Termite resistance of wood-plastic composites treated with zinc borate and borax. Journal of Thermoplastic Composite Materials, 29 (2): 281-293. https://doi.org/10.1177/0892705714563343.

16. Luo, S. P.; Cao, J. Z.; Wang, X., 2012: Properties of PEG/ thermally modified wood flour/polypropylene (PP) composites. Forestry Studies in China, 14 (4): 307-314. https://doi.org/ 10.1007/s11632-012-0405-x.

17. Naumann, A.; Stephan, I.; Noll, M., 2012: Material resistance of weathered wood-plastic composites against fungal decay. International Biodeterioration and Biodegradation, 75: 28-35. https://doi.org/10.1016/j.ibiod.2012.08.004.

18. Pelaez-Samaniego, M., R.; Yadama, V.; Lowell, E.; Espinoza-Herrera, R., 2013: A review of wood thermal pretreatments to improve wood composite properties. Wood Science and Technology, 47 (6): 1285-1319. https://doi.org/10.1007/s00226-013-0574-3.

19. Pilarski, J. M.; Matuana, L. M., 2005: Durability of wood flour-plastic composites exposed to accelerated freezethaw cycling, part I: Rigid PVC matrix. Journal of Vinyl and Additive Technology, 11: 1-8. http://doi.org/10.1002/vnl.20029.

20. Sagitova, E. A.; Donfack, P.; Nikolaeva, G. Y.; Prokhorov, K. A.; Pashinin, P. P.; Nedorezova, P. M.; Materny, A., 2017: New insights into the structure of polypropylene polymorphs and propylene copolymers probed by lowfrequency Raman spectroscopy. Journal of Physics: Conference Series (vol. 826, no. 1, p. 012006). IOP Publishing.

21. Segerholm, B. K.; Ibach, R., E.; Westin, M., 2012: Moisture sorption, biological durability, and mechanical performance of WPC containing modified wood and polylactates. BioResources, 7(4): 4575-4585.

22. Selden, R.; Nystrom, B.; Langstrom, R., 2004: UV aging of poly (propylene) / wood-fiber composites. Polymer Composite, 25: 543-553.

https://doi.org/10.1002/pc.20048.

23. Stark, N. M.; Gardner, D. J., 2008: Outdoor durability of wood-polymer composites. Woodhead Publishing, Philadelphia.

24. Turku, I.; Karki, T., 2016: Accelerated weathering of wood-polypropylene composite containing carbon fillers. Journal of Composite Materials, 50 (10): 1387-1393. https://doi.org/10.1177/0021998315591842.

25. Xing, D.; Wang, S.; Li, J., 2015: Effect of artificial weathering on the properties of industrial scale thermally modified wood. BioResources, 10 (4): 8238-8252.

26. Yilgor, N.; Köse, C.; Terzi, E.; Figen, A. K.; Ibach, R.; Kartal, S. N.; Pişkin, S., 2014: Degradation behavior and accelerated weathering of composite boards produced from waste Tetra Pak ${ }^{\circledR}$ packaging materials. BioResources, 9 (3): 4784-4807.

27. Žlahtič-Zupanc, M.; Lesar, B.; Humar, M., 2018: Changes in moisture performance of wood after weathering. Construction and Building Materials, 193: 529-538. https://doi.org/10.1016/j.conbuildmat.2018.10.196.

\section{Corresponding address:}

DENIZ AYDEMIR, Ph.D.

Bartin University

Faculty of Forestry

Department of Forest Industrial Engineering

74100, TURKEY

e-mail: denizaydemir@bartin.edu.tr 